\title{
EVALUASI PROGRAM BIDANG PEMBERDAYAAN NELAYAN DALAM MENINGKATKAN KESEJAHTERAAN MASYARAKAT NELAYAN DI DINAS PERIKANAN KABUPATEN PAMEKASAN PROVINSI JAWA TIMUR
}

\author{
Oleh \\ Agus Sulaiman Bolkiah', \\ Muh. Ilham², Etin Indrayani ${ }^{3}$ \\ 1) Institut Pemerintahan Dalam Negeri \\ Program Magister Terapan Studi Pemerintahan Daerah Institut Pemerintahan Dalam Negeri \\ agusbolkiah@gmail.com \\ ${ }^{2,3)}$ Institut Pemerintahan Dalam Negeri
}

\begin{abstract}
"EVALUATION OF FISHERMAN EMPOWERMENT PROGRAMS IN IMPROVING FISHERMAN COMMUNITY WELFARE IN DINAS PERIKANAN, PAMEKASAN DISTRICT, WEST JAVA PROVINCE”
\end{abstract}

$T$

he large marine and fisheries potentials that are owned should be developed in order to support the increase in the economic growth of fishing communities. Pamekasan Regency Government, especially the Department of Maritime Affairs and Fisheries, conducts community empowerment activities for fishermen. This research is focused on how to evaluate the community empowerment program in improving the welfare offishermen in the Pamekasan Regency fisheries office. Then also look at the program strategy undertaken in overcoming the inhibiting factors for the evaluation of the program. The research method used is qualitative research with a descriptive approach. The data obtained in this study were collected through interviews with selected respondents through snowball sampling, document review and field observations. The results of this study indicate that there are still many evaluations of community empowerment programs in improving the welfare of fishermen in the fisheries office of Pamekasan Regency, which is a big task for local governments to make it a success. Apart from the relatively small budget, access to information, provision of facilities and infrastructure is still inadequate. Meanwhile, the capture fisheries production in Pamekasan Regency tends to increase from year to year by the fishing community. So that the local government of Pamekasan Regency is deemed necessary to accommodate the interests of the fishing community in Pamekasan Regency. Capture fisheries production in Pamekasan Regency tends to increase from year to year by the fishing community. So that the local government of Pamekasan Regency is deemed necessary to accommodate the interests of the fishing community in Pamekasan Regency.

Keywords: community empowerment, evaluation, fisherman, welfare.

\section{AbSTRAK}

$\mathrm{B}$ esarnya potensi kelautan dan perikanan yang dimiliki, sudah selayaknya dikembangkan agar dapat mendukung peningkatan pertumbuhan ekonomi masyarakat nelayan. Pemerintah Kabupaten Pamekasan khususnya Dinas Kelautan dan Perikanan melakukan kegiatan pemberdayaan masyarakat nelayan. Penelitian ini difokuskan kepada bagaimana 
evaluasi program bidang pemberdayaan masyarakat dalam meningkatkan kesejahteraan nelayan di dinas perikanan Kabupaten Pamekasan. Kemudian juga melihat strategi program yang dilakukan dalam mengatasi faktor penghambat evaluasi program tersebut. Metode penelitian yang digunakan adalah penelitian kualitatif dengan melakukan pendekatan secara deskriptif. Data-data yang didapat dalam penelitian ini dikumpulkan melalui wawancara terhadap responden yang dipilih melalui snowball sampling, menelaah dokumen serta observasi lapangan. Hasil penelitian ini menunjukkan bahwa evaluasi program bidang pemberdayaan masyarakat dalam meningkatkan kesejahteraan nelayan di dinas perikanan Kabupaten Pamekasan masih banyak yang menjadi tugas besar bagi pemerintah daerah untuk menyukseskannya. Selain anggaran yang terbilang masih sedikit, akses informasi, pengadaan sarana dan prasarana yang terbilang masih sangat kurang memadai. Sedangkan, produksi perikanan tangkap di Kabupaten Pamekasan cenderung dari tahun ke tahun meningkat didapat oleh masyarakat nelayan. Sehingga pemerintah daerah Kabupaten Pamekasan dirasa sangat perlu untuk mengakomodasi kepentingan-kepentingan bagi masyarakat nelayan di Kabupaten Pamekasan.

Kata kunci: evaluasi, kesejahteraan, nelayan, pemberdayaan masyarakat.

\section{PENDAHULUAN}

$\mathrm{I}$ ndonesia secara geografis merupakan negara kepulauan terbesar di dunia, dengan 17.502 pulau, serta luas wilayah laut sekitar 5,8 juta $\mathrm{km}^{2}$, yang terdiri dari perairan kepulauan dan teritorial seluas 3,1 juta $\mathrm{km}^{2}$ serta perairan Zona Ekonomi Eksklusif Indonesia (ZEEI) seluas 2,7 juta $\mathrm{km}^{2}$ (Surono, 2015). Berdasarkan kondisi tersebut, Indonesia memiliki garis pantai terpanjang kedua di dunia, yakni mencapai $95.181 \mathrm{~km}$. Hal ini menempatkan Indonesia sebagai negara yang memiliki jumlah populasi nelayan yang patut untuk diperhitungkan serta potensi sumber daya kelautan dan perikanan yang sangat besar (Salam, 2008). Melimpahnya kekayaan maritim Indonesia akan berperan penting serta dapat berkontribusi bagi pertumbuhan sektor ekonomi Indonesia.

Kenyataannya, kehidupan nelayan di wilayah pesisir Indonesia yang hidupnya bergantung pada hasil laut, menggunakan teknologi tradisional dalam pola mata pencahariannya. Selain alat tangkap mereka sudah jauh tertinggal, mereka melaut juga pada area penangkapan yang terbatas di wilayah pesisir. Rendahnya daya jelajah nelayan ini, semakin menambah sulit nelayan memperbaiki kualitas hidupnya. Selain itu, sebagian besar anggota keluarga masyarakat pesisir termasuk anggota keluarga tidak produktif dari segi ekonomi dalam arti anggota keluarga hanya menggantungkan nasib pada hasil tangkapan ikan (Ardianti, 2019).

Salah satu wilayah yang menjadikan sektor perikanan sebagai pusat perekonomiannya adalah Pulau Madura. Hal ini dikarenakan, secara geografis Madura merupakan daerah pesisir yang dikelilingi oleh pantai terutama di sisi utara dan selatan. Meskipun letaknya secara administratif dalam wilayah Provinsi Jawa Timur, namun letaknya terpisah dari Pulau Jawa.

Berdasarkan statistik Data Kelautan dan Perikanan (2018) mengenai volume produksi perikanan tangkap laut, pada 2017 adalah 19\% dari volume produksi untuk wilayah Provinsi Jawa Timur. Salah satu bagian dari daerah pesisir wilayah Madura adalah Kabupaten Pamekasan yang menjadi perhatian dalam penelitian ini.

Kabupaten Pamekasan merupakan kabupaten dengan Indeks Pembangunan Manusia tertinggi dibandingkan kabupaten lain di wilayah Madura, menjadikan Pamekasan dengan persentase penduduk miskin terendah dibandingkan ketiga kabupaten lainnya. 
Tabel 1. Jumlah Penduduk Miskin Kabupaten di Pulau Madura

\begin{tabular}{llcccc}
\hline \multirow{2}{*}{ No. } & \multirow{2}{*}{ Kabupaten } & \multicolumn{2}{c}{$\begin{array}{c}\text { Jumlah Penduduk Miskin } \\
\text { (Ribu) }\end{array}$} & $\begin{array}{c}\text { Persentase Penduduk Miskin } \\
\text { Jawa Timur }\end{array}$ \\
\cline { 3 - 6 } & & $\mathbf{2 0 1 7}$ & $\mathbf{2 0 1 8}$ & $\mathbf{2 0 1 7}$ & $\mathbf{2 0 1 8}$ \\
\hline 1 & Bangkalan & 206,53 & 191,33 & 21,32 & 19,59 \\
2 & Sampang & 225,13 & 204,82 & 23,56 & 21,21 \\
3 & Pamekasan & 137,77 & 125,76 & 16,00 & 14,47 \\
4 & Sumenep & 211,92 & 218,60 & 19,62 & 20,16 \\
\hline
\end{tabular}

Sumber: BPS Provinsi Jawa Timur, 2019

Salah satu sektor yang mendukung keberhasilan Kabupaten Pamekasan dalam mengupayakan peningkatan kualitas hidup masyarakat adalah sektor perikanan. Berdasarkan Data Kelautan dan Perikanan Provinsi Jawa Timur (2018), Kabupaten Pamekasan menyumbangkan 21\% dari total volume produksi perikanan wilayah Madura.

Kabupaten Pamekasan melalui Dinas Perikanan mengadakan Program Pengembangan Bidang Pemberdayaan nelayan dengan pemberian bantuan alat pancing tangkap ikan, alat bantu komunikasi, serta fishsinder GPS sebagai alat pelacak (Bolkiah, 2016). Program tersebut bertujuan untuk mengoptimalisasi potensi sumber daya alam laut yang telah dimiliki sehingga dapat menunjang perekonomian rumah tangga masyarakat, terutama yang berprofesi sebagai nelayan.

Akan tetapi dalam perkembangannya, ternyata jumlah pengembangan atau penambahan peralatan tangkap ikan tidak sejalan dengan jumlah produksi ikan, khususnya perikanan tangkap. Produksi perikanan si Kabupaten Pamekasan mengalami penurunan dari Tahun 2016 sejumlah 23.190 ton, menurun 21.689 ton pada 2017 dan 2018 menurun kembali hingga $19.554,1$ ton.

Hal ini dikarenakan program pemberdayaan masyarakat nelayan oleh
Dinas Perikanan hanya memberikan sosialisasi penggunaan alat tangkap ikan tanpa diikuti dengan pengawasan lebih lanjut. Pengawasan yang belum dilaksanakan oleh program tersebut berupa pendampingan dan pembimbingan secara berkala oleh pemerintah setempat.

Demikian halnya terjadi pada penelitian terdahulu oleh Qodriyatun (2013) dalam penelitiannya menunjukkan bahwa pemberian modal tidak menjamin keberhasilan suatu program. Poin penting justru ada pada bagaimana pemerintah memberdayakan masyarakat untuk memaksimalkan modal dan sumber daya yang dimiliki untuk mencapai keberhasilan dari tujuan program tersebut.

Tak jauh berbeda penelitian tentang "Pemberdayaan Masyarakat Pesisir dalam Upaya Meningkatkan Ekonomi di Dusun Pangkungdedari, Desa Melaya, Kecamatan Melaya" (Iswari dkk., 2019) menyebutkan bahwa pelaksanaan program tanpa adanya arahan dan pendampingan menjadikan program berjalan stagnan. Sehingga program yang dicanangkan tentu tidak mencapai tujuan yang diharapkan.

Ketidaksesuaian atas harapan dari pelaksanaan Program Pengembangan Bidang Pemberdayaan Nelayan, menjadi pertanyaan yang mendasari penulis dalam mengkaji program yang telah dilaksanakan selama empat tahun terakhir tersebut. 


\section{KAJIAN PUSTAKA}

\section{Evaluasi}

Evaluasi merupakan proses yang berkaitan dengan mengukur dan menilai (Arikunto, 2015). Ripley dan Franklin dalam Winarno berpendapat bahwa evaluasi merupakan apa yang terjadi setelah penetapan undang-undang sehingga memberikan otoritas program, kebijakan, dan keuntungan. Selain itu, Nugroho menjelaskan bahwa evaluasi memiliki fungsi berikut ini.

a. Eksplanasi, memperoleh gambaran realita dari pelaksanaan program sehingga dapat digeneralisasikan dalam bentuk pola hubungan antara dimensi0dimensi yang diamati. Sehingga evaluator dapat mengidentifikasikan masalah, kondisi, dan aktor pendukung keberhasilan atau kegagalan kebijakan tersebut.

b. Kepatuhan. Evaluasi menunjukkan apakah tindakan yang dilakukan oleh pelaku kebijakan sesuai standar dan prosedur yang ditetapkan oleh kebijakan.

c. Audit. Melalui audit diketahui apakah output yang diharapkan sampai kepada sasaran kebijakan. Atau justru terjadi penyimpangan dan kebocoran dari tujuan kebijakan tersebut.

d. Akunting. Dengan evaluasi dapat diketahui apa akibat sosial ekonomi dari kebijakan tersebut.

\section{Pemberdayaan Masyarakat}

Pemberdayaan masyarakat (Sidabalok \& Marina, 2005) pada dasarnya merupakan konsep memperkuat potensi (empowerment) masyarakat sebagai individu sebagai subjek dan memberi ruang partisipasi penuh mereka ke dalam program pemberdayaan tersebut. Inisiatif kreatif dari masyarakat merupakan sumber daya yang utama. Partisipasi mereka mulai dari perencanaan, pelaksanaan, monitoring hingga pada evaluasi program.

Pemberdayaan masyarakat menurut (Karubaba dkk., 2014) adalah upaya untuk mentransformasikan pertumbuhan masyarakat sebagai kekuatan nyata masyarakat, untuk melindungi dan memperjuangkan nilai-nilai dan kepentingan di dalam arena segenap aspek kehidupan. Pemberdayaan masyarakat mempunyai arti meningkatkan kemampuan atau meningkatkan kemandirian masyarakat. Upaya pemberdayaan rakyat mencakup 3-P yaitu,

$\begin{array}{lcr}\text { a. } & \begin{array}{l}\text { Pendampingan } \\ \text { menggerakkan }\end{array} \\ \text { masyarakat; } & \text { partisipasi } & \begin{array}{r}\text { dapat } \\ \text { total }\end{array} \\ & & \end{array}$

b. Penyuluhan dapat merespons dan membantu perubahan-perubahan yang terjadi di masyarakat; dan

c. Pelayanan yang berfungsi sebagai pengendali ketepatan distribusi aset sumber daya fisik dan nonfisik yang diperlukan oleh masyarakat.

\section{METODE PENELITIAN}

Penelitian dilakukan pada 2020, dengan mengambil lokasi di wilayah pesisir Kabupaten Pamekasan. Penelitian ini merupakan jenis penelitian kualitatif dengan metode studi kasus (case study). Metode ini digunakan karena memiliki fokus penelitian terhadap sebuah kasus yang dapat mencakup individu, kelompok budaya, ataupun sebuah potret kehidupan (Creswell, 2012). Data yang digunakan dalam penelitian ini adalah data primer dan sekunder. Data primer dan data sekunder merupakan data kualitatif yang bersifat deskriptif. Data primer tersebut bersumber dari penelitian di lapangan melalui wawancara dengan informan dan hasil observasi proses pelaksanaan program serta dampak yang dihasilkan oleh keterlaksanaan program. Data sekunder bersumber dari 
data pendukung melalui analisis dokumen terkait. Pemilihan informan dalam wawancara diperoleh dengan cara snowball sampling. Data diperoleh peneliti melalui wawancara, observasi dan dokumentasi. Kerangka analisis mengacu pada tiga alur yang disampaikan oleh Miles dan Huberman (Sugiyono, 2015) meliputi reduksi data, penyajian data dan penarikan simpulan. Model ini dipilih agar dapat mengakomodasi perkembangan data yang diperoleh di luar data primer. Di samping itu sumber data yang telah dikumpulkan dicek kembali untuk memperoleh keabsahan data sehingga dapat dipertanggungjawabkan.

\section{HASIL PENELITIAN DAN PEMBAHASAN}

Evaluasi program adalah metode sistematik untuk mengumpulkan, menganalisis, dan memakai informasi untuk menjawab pertanyaan dasar mengenai program. Evaluasi program dapat dikelompokkan menjadi evaluasi proses (process evaluation), evaluasi manfaat (outcome evaluation) dan evaluasi akibat (impan evaluation). Evaluasi proses meneliti dan menilai apakah intervensi atau layanan program telah dilaksanakan seperti yang direncanakan; dan apakah target populasi yang direncanakan telah dilayani. Evaluasi ini juga menilai strategi pelaksanaan program. Evaluasi bermanfaat untuk meneliti, menilai, dan menentukan apakah program telah menghasilkan perubahan yang diharapkan.

\section{Context Evaluation}

Evaluasi ini mengidentifikasi permasalahan, aset, dan peluang untuk membantu para pengambil keputusan untuk merencanakan program yang akan berlangsung, meliputi analisis personel yang berkaitan dengan bagaimana penggunaan sumber-sumber yang tersedia, alternatif strategi yang menjadi pertimbangan dalam mencapai suatu program. Evaluasi masukan akan mengidentifikasi dan menilai kapabilitas sistem, alternatif strategi program, desain prosedur untuk strategi implementasi, pembiayaan dan penjadwalan. Evaluasi masukan bermanfaat untuk pemilihan strategi program dalam mengkhususkan rancangan procedural dan upaya memperoleh rencana program yang efektif dan efisien.

Dari observasi penulis, dilihat dari topologis wilayah Kabupaten Pamekasan yang sebelah utara dan selatan berbatasan dengan lautan. Seharusnya pemberdayaan masyarakat nelayan ini menjadi bagian khusus dalam visi misi kabupaten Pamekasan. Hal ini karena laut menjadi salah satu mata pencarian penduduk di Kabupaten Pamekasan. Tetapi hal ini tidak terlalu dipertimbangkan dalam visimisi Kabupaten Pamekasan. Diharapkan nantinya pemberdayaan masyarakat nelayan ini menjadi fokus Pemerintah Kabupaten Pamekasan.

Menurut Badrujaman (2011) sasaran utama dari evaluasi terhadap konteks (context evaluation) adalah untuk menelaah status objek secara keseluruhan sehingga dapat memberikan deskripsi mengenai karakteristik lingkungan. Pada pelaksanaan layanan informasi, evaluasi terhadap context bertujuan untuk mengetahui apakah tujuan yang lama dan prioritas telah sesuai dengan kebutuhan layanan.

Dilihat dari teori tersebut, penelitian ini mengenai pemberdayaan masyarakat nelayan di Kabupaten Pamekasan, secara umum telah memenuhi evaluasi konteks. Tujuan dari program pemberdayaan telah sesuai dengan yang diharapkan, walaupun masih banyak evaluasi yang harus di laksanakan dalam pelaksanaannya.

\section{Input Evaluation}

Evaluasi ini mengidentifikasi permasalahan, aset, dan peluang untuk membantu para pengambil keputusan untuk merencanakan program yang akan 
berlangsung, meliputi analisis personel yang berkaitan dengan bagaimana penggunaan sumber-sumber yang tersedia, alternatif strategi yang menjadi pertimbangan dalam mencapai suatu program. Evaluasi masukan akan mengidentifikasi dan menilai kapabilitas sistem, alternatif strategi program, desain prosedur untuk strategi implementasi, pembiayaan dan penjadwalan. Evaluasi masukan bermanfaat untuk pemilihan strategi program dalam mengkhususkan rancangan procedural dan upaya memperoleh rencana program yang efektif dan efisien.

Selanjutnya mengenai Input Evaluation dijelaskan lebih rinci dalam faktor-faktor yang memengaruhi pengembangan program bidang pemberdayaan masyarakat dalam rangka meningkatkan kesejahteraan masyarakat nelayan oleh Dinas Perikanan di Kabupaten Pamekasan adalah masih kurangnya bimbingan dan pengawasan dari dinas terkait penggunaan atau pemanfaatan sarana dan prasarana yang diberikan oleh pemerintah pusat melalui Dinas Perikanan Kabupaten pamekasan. Contoh saja seperti penggunaan GPS untuk mengetahui letak mengumpulnya ikan di lautan, para nelayan beranggapan bahwa teknologi tersebut tidak bisa digunakan di tengah laut dikarenakan faktor jaringan.

\section{Process Evaluation}

Evaluasi proses meliputi koleksi data kegiatan yang telah ditentukan dan diterapkan dalam praktik pelaksanaan program. Pada dasarnya evaluasi proses untuk mengetahui sampai sejauh mana rencana akan diterapkan dan komponen apa yang perlu dilakukan.

Berdasarkan data Tabel 2, diketahui bahwa penambahan atau pengembangan program bidang pemberdayaan nelayan dengan bantuan alat penangkapan ikan dan alat bantu penangkapan ikan serta pelatihan penggunaan alat untuk meningkatkan produksi ikan tidak sesuai dengan harapan. Hal tersebut juga disebabkan kurangnya pengawasan pemerintah dalam penggunaan alat yang sudah didistribusikan secara tepat guna. Selain itu, berdasarkan observasi di lapangan, masih terdapat banyak rumah tangga yang belum mencapai kesejahteraan. Hal tersebut menimbulkan pertanyaan terkait program yang telah dilaksanakan, sehingga diperlukan pengkajian terhadap program yang diterapkan.

\section{Product Evaluation}

Evaluasi ini berupaya mengidentifikasi dan mengakses keluaran dan manfaat, baik yang direncanakan maupun tidak direncanakan, baik jangka pendek maupun

Tabel 2. Jumlah Produksi Perikanan Tangkap Menurut Kecamatan 2017-2019 (ton)

\begin{tabular}{rlrrr}
\hline \multirow{2}{*}{ No. } & \multirow{2}{*}{ Kecamatan } & \multicolumn{3}{c}{ Tahun } \\
\cline { 3 - 5 } & & $\mathbf{2 0 1 7}$ & $\mathbf{2 0 1 8}$ & \multicolumn{1}{c}{$\mathbf{2 0 1 9}$} \\
\hline 1 & Tlanakan & - & $10.633,2$ & $11.233,2$ \\
2 & Pademawu & - & $5.015,4$ & $3.226,8$ \\
3 & Galis & - & 166,6 & 591,5 \\
4 & Larangan & - & $2.492,8$ & 794,8 \\
5 & Kadur & - & 0 & 105,5 \\
6 & Batumarmar & - & $1.352,9$ & 856,2 \\
7 & Pasean & - & $2.028,1$ & $2.746,1$ \\
\hline & Total & 23.190 & 21.689 & $19.554,1$ \\
\hline
\end{tabular}

Sumber: BPS Kab. Pamekasan Tahun 2017-2019 
jangka panjang. Pada evaluasi konteks, evaluasi input, dan evaluasi proses, kemudian diinterpretasikan harga dan jasa yang diberikan. Evaluasi ini merupakan catatan pencapaian hasil dan keputusankeputusan untuk perbaikan kegiatan yang sedang berlangsung, serta memutuskan perlu diperbaiki, dilanjutkan, atau dihentikan program tersebut.

Berdasarkan data BPS Kabupaten Pamekasan 2017-2019, jumlah pengembangan atau penambahan peralatan tangkap ikan tidak sejalan dengan jumlah produksi ikan, khususnya perikanan tangkap. Hal ini dikarenakan program pemberdayaan masyarakat nelayan oleh Dinas Perikanan hanya memberikan sosialisasi penggunaan alat tangkap ikan tanpa adanya pengawasan yang lebih lanjut.

Pengawasan yang belum dilaksanakan oleh program tersebutberupa pendampingan dan pembimbingan yang dilakukan secara berkala oleh pemerintah setempat. Berikut disajikan jumlah produksi perikanan tangkap pada 2017-2019 menurut kecamatan di Kabupaten Pamekasan.

\section{Evaluasi Program Bidang Pember- dayaan Nelayan dalam Meningkatkan Kesejahteraan Masyarakat Nelayan}

Melalui pendekatan Input Evaluation yang mengidentifikasi permasalahan,

Tabel 3. Jumlah Sarana Perikanan Nelayan Kabupaten Pamekasan 2017-2019

\begin{tabular}{clrrr}
\hline \multirow{2}{*}{ No. } & \multicolumn{3}{c}{ Jenis Sarana } & \multicolumn{3}{c}{ Tahun } \\
\cline { 2 - 5 } & $\mathbf{2 0 1 7}$ & $\mathbf{2 0 1 8}$ & $\mathbf{2 0 1 9}$ \\
\hline 1 & Perahu Tanpa Motor & - & 0 & 67 \\
2 & Perahu Motor Tempel & - & 1.636 & 1.313 \\
3 & Jukung & & & \\
& $<10$ GT & - & 130 & 347 \\
& $10-30$ GT & - & 28 & 57 \\
& $>$ 30 GT & - & 0 & 1 \\
4 & Jaring Lingkar Bertali Kerut & - & 105 & 63 \\
5 & Payang & 867 & 859 & 729 \\
6 & Jaring Insang Hanyut & 165 & 370 & 523 \\
7 & Jaring Insang Tetap & 414 & - & 443 \\
8 & Centrang & - & 33 & 116 \\
9 & Pancing Ulur & 74 & 53 & 60 \\
10 & Bubu & 37 & 24 & 138 \\
11 & Bagan Perahu & 49 & 24 & 53 \\
12 & Tonda & - & 157 & 126 \\
13 & Trammel & 105 & - & 68 \\
14 & Dogol & - & - & 25 \\
15 & Jala Tebar & 83 & - & 68 \\
16 & Alat Penggaruk Tanpa Kapal & - & - & 660 \\
17 & Alat Penggaruk Kapal & - & - & 3 \\
\hline & & & &
\end{tabular}

Sumber: BPS Kabupaten Pamekasan Tahun 2017-2019 
aset, dan peluang untuk membantu para pengambil keputusan untuk merencanakan program yang akan berlangsung, meliputi analisis personel yang berkaitan dengan bagaimana penggunaan sumber-sumber yang tersedia, alternatif strategi yang menjadi pertimbangan dalam mencapai suatu program.

Kabupaten Pamekasan merupakan Kabupaten yang memiliki wilayah pesisir yang terbentang pada garis pantai sepanjang $\pm 52 \mathrm{~km}$, pantai selatan sepanjang $34 \mathrm{~km}$ yang mencakup empat wilayah pesisir (Kecamatan Tlanakan, Pademawu, Larangan, dan Galis. Sedangkan pantai utara sepanjang $18 \mathrm{~km}$ terdiri dari dua wilayah pesisir (Kecamatan Pasean dan Batumarmar).

Dengan otonomi daerah, maka setiap pemerintah daerah dituntut untuk meningkatkan kesejahteraan masyarakatnya dengan memanfaatkan semua potensi daerah yang dimilikinya. Sumber daya perikanan sebagai salah satu bentuk potensi sumber daya alam Kabupaten Pamekasan diharapkan dapat memberikan sumbangan pada peningkatan kesejahteraan rakyat khususnya pelaku usaha perikanan. Kabupaten Pamekasan memiliki potensi sumber daya perikanan cukup besar baik laut maupun darat dan memiliki potensi sumber daya perikanan cukup besar baik laut maupun darat dan memiliki prospek yang baik untuk dikembangkan di Kabupaten Pamekasan mencakup perikanan tangkap/ laut, perikanan budi daya dan pengolahan hasil perikanan. Komoditi perikanan yang potensial di Kabupaten Pamekasan, yaitu garam, ikan teri dan rumput laut. Komoditi perikanan lain yang potensial, yaitu budi daya udang vannamei pada lahan tambak dan budi daya air tawar khususnya ikan lele.

Dalam Undang-Undang No. 23 Tahun 2014 tentang Pemerintahan Daerah pada Pasal 12 ayat (3) dijelaskan bahwa adanya urusan pilihan yang menjadi kewajiban pemerintah daerah dalam melaksanakan proses pemerintahan. Salah satu urusan pilihan yang di ambil oleh Kabupaten Pamekasan adalah mengenai kelautan dan perikanan. Dalam objek penelitian sangat jelas bahwa gambaran topologis wilayah Kabupaten Pamekasan di apit oleh dua lautan dan dua daratan. Sebelah utara dan selatan berbatasan dengan laut, sedangkan timur dan barat berbatasan dengan daerah lainnya. Oleh karena itu urusan kelautan dan perikanan sejatinya memang harus diurus oleh Kabupaten Pamekasan.

Melalui keterangan yang diberikan oleh pihak Pemerintah Daerah Kabupaten Pamekasan, yang dalam hal ini Kepala Dinas dan Sekretaris Dinas Perikanan bahwa sejatinya dalam Program Pengembangan Perikanan Tangkap, Program Pengembangan Kawasan Budi Daya Laut, Air Payau dan Air Tawar Sarana dan Prasarana yang dimiliki cukup memadai. Namun, masih adanya kekurangan peralatan alat tangkap dan alat bantu bagi nelayan. Dan juga, dibutuhkannya tempat pelelangan ikan yang masih menjadi kendala oleh pihak Pemerintah Daerah untuk memenuhi kebutuhan terhadap pasar ikan di Kabupaten Pamekasan.

Mengenai Sumber Daya Nelayan, pihak Pemerintah Daerah membentuk sebuah kelompok nelayan yang bertujuan untuk dilakukannya pelatihan atau di didik dan disalurkan bantuan kepadanya, kemudian para nelayan juga meneruskan bantuan tersebut kepada sesama nelayan. Namun, sesuai dengan yang diutarakan oleh masyarakat nelayan, dalam kegiatan ini sangat disayangkan masih minimnya akses informasi kepada para nelayan secara menyeluruh.

Sesuai keterangan oleh pihak Pemerintah Daerah Kabupaten Pamekasan bahwa penganggaran untuk alat bantu tangkap diketahui sebesar \pm Rp280.000.000,00 per tahun, yang dalam hal ini pelaksanaan program terhadap anggaran tersebut hanya dicukup-cukupkan saja. Yang juga dikeluhkan 
oleh masyarakat nelayan bahwa masih banyaknya nelayan yang belum mendapatkan dana tersebut dan salah satunya juga disebabkan oleh kurang validnya pendataan terhadap rasio masyarakat nelayan.

Dengan membentuk tim penyuluhan, Pemerintah Daerah melalui penyuluh menugaskan untuk memberikan penyuluhan dan pemberdayaan kepada masyarakat nelayan Kabupaten Pamekasan. Dalam hal ini, juga diberikan pelatihan-pelatihan kepada masyarakat nelayan dengan mendatangkan berbagai narasumber dalam menyosialisasikan berbagai program pemberdayaan oleh Pemerintah Daerah Kabupaten Pamekasan.

Program pemberdayaan yang diadakan oleh Pemerintah Daerah seperti pengadaan alat bantu tangkap ikan setiap tahunnya yang disalurkan kepada kelompok nelayan yang telah dibentuk dan terdaftar, sosialisasi peraturan terkait aturan melaut terutama dalam pelaporan hasil tangkapan ikan. Dan menurut keterangan beberapa masyarakat nelayan, telah didapat adanya pemberian asuransi oleh pihak Pemerintah Daerah Kabupaten Pamekasan kepada masyarakat nelayan, dan pemberian alat safety untuk melaut.

Dapat disimpulkan bahwa dalam input evaluasi ini ada beberapa hal yang harus diperhatikan oleh Pemerintahan Kabupaten Pamekasan, salah satunya anggaran yang masih tergolong kecil. Pemerintah Kabupaten Pamekasan telah membentuk kelompok-kelompok nelayan sebagai tempat melaksanakan pemberdayaan. Hal ini juga masih dinilai kurang, karena tidak semua nelayan yang bergabung dalam kelompok nelayan. Tim penyuluh pun sudah melakukan penyuluhan melalui kelompok-kelompok nelayan yang ada. kanan sejatinya memang harus di urus oleh Kabupaten Pamekasan.

Dalam pendekatan Process Evaluation yang meliputi koleksi data kegiatan yang telah ditentukan dan diterapkan dalam praktik pelaksanaan program. Pada dasarnya evaluasi proses untuk mengetahui sampai sejauh mana rencana akan diterapkan dan komponen apa yang perlu dilakukan.

Mengenai persiapan terkait program pemberdayaan nelayan, diketahui bahwa pihak Pemerintah Daerah telah membahas di DPRD dan dipersiapkan melalui pelaksanaan diwilayah kewenangan Dinas Perikanan, yang kemudian disalurkan kepada masyarakat nelayan. Namun, masih terdapatnya kendala pada proses pelaksanaan, yakni tidak semua masyarakat nelayan mendapatkan bantuan. Hal ini dikarenakan anggaran yang diperuntukkan kepada program ini kecil, dan Pemerintah Daerah terus berupaya untuk meningkatkan anggaran terkait program ini. Hal tersebut juga diamini oleh beberapa nelayan bahwa dalam pelaksanaan program masih ada beberapa nelayan yang tidak mendapatkan informasi untuk kegiatan serta belum efektifnya program tersebut dilaksanakan oleh Pemerintah Daerah bagi kalangan masyarakat nelayan.

Kendala yang kerap terjadi pada proses pelaksanaan program tersebut, yakni tidak semua masyarakat mendapatkan alat bantu penangkapan. Pemerintah Daerah melalui Dinas Perikanan terus mengakalinya dengan memberikan bantuan bergiliran kepada nelayan melalui kelompok nelayan yang telah dibentuk. Pun, melalui pernyataan masyarakat kendala yang sering terjadi, yakni sulitnya akses administrasi terkait perizinan kepada pemerintah yang sangat berbelitbelit, ditambah banyaknya pungli oleh oknum yang terjadi di wilayah pencaharian masyarakat nelayan Kabupaten Pamekasan.

Melalui Rencana Pembangunan Jangka Menengah Daerah (RPJMD), Pemerintah Daerah berupaya meningkatkan anggaran dalam program pemberdayaan masyarakat nelayan. Yang Pada ini diperkirakan anggaran sekitar \pm Rp1.200.000.000,00 untuk program pemberdayaan nelayan tersebut, yang dilaksanakan secara bertahap. Dan 
harapan yang besar dari masyarakat bahwa lebih ditingkatkannya akses informasi dari Pemerintah Daerah terkait pemberdayaan nelayan kepada masyarakat nelayan secara umum, secara jelas dan transparan. Diharapkan melalui informasi yang mudah dijangkau oleh masyarakat nelayan dapat tersosialisasinya program pemberdayaan nelayan oleh Pemerintah Daerah Kabupaten Pamekasan, serta ketatnya penegakan hukum terhadap oknum yang kerap kali melakukan praktik pungutan liar (pungli).

\section{SIMPULAN}

Pemerintahan Daerah Kabupaten Pamekasan telah meletakkan program pemberdayaan masyarakat nelayan ini dalam visi-misi Kabupaten Pamekasan. Meskipun tidak ada aspek khusus terkait nelayan dalam visi-misinya hal ini tidak dilupakan oleh Kabupaten Pamekasan. Banyak evaluasi yang diberikan masyarakat beserta harapan masyarakat dalam hal pemberdayaan ini.

Kondisi topologis sangat memengaruhi program pemberdayaan ini. Di mana kondisi Kabupaten Pamekasan ini diapit oleh dua laut sebelah utara dan selatan, sehingganya menuntut pemerintah untuk meningkatkan anggaran dalam pelaksanaan program anggaran yang masih tergolong kecil. Pemerintah Kabupaten Pamekasan telah membentuk kelompok-kelompok nelayan sebagai tempat melaksanakan pemberdayaan. Hal ini juga masih dinilai kurang, karena tidak semua nelayan yang bergabung dalam kelompok nelayan. Tim penyuluh pun sudah melakukan penyuluhan melalui kelompok-kelompok nelayan yang ada.

Kendala pada proses pelaksanaan, yakni tidak semua masyarakat nelayan mendapatkan bantuan. Melalui informasi yang mudah dijangkau oleh masyarakat nelayan dapat tersosialisasinya program pemberdayaan nelayan oleh Pemerintah
Daerah Kabupaten Pamekasan, serta ketatnya penegakan hukum terhadap oknum yang kerap kali melakukan praktik pungutan liar (pungli).

\section{SARAN}

Diharapkan, adanya pengoptimalisasian pelaksanaan program yang maksimal oleh Pemerintah Daerah Kabupaten Pamekasan terkait program pemberdayaan nelayan dalam rangka meningkatkan kesejahteraan nelayan. Seharusnya pihak Pemerintah Daerah harus berupaya mengakomodasi kepentingan masyarakat nelayan dalam memenuhi kebutuhan perekonomian.

Pemerintah Daerah lebih meningkatkan anggaran terhadap program pemberdayaan nelayan dalam rangka meningkatkan kesejahteraan nelayan. Lebih berupaya untuk meningkatkan akses informasi dan sosialisasi program pemberdayaan nelayan. Serta, harus diketatkannya penegakan hukum terhadap oknum yang melakukan pungli kepada masyarakat nelayan.

Melalui banyaknya hasil produksi yang didapati oleh masyarakat nelayan, pemerintah juga seharusnya menjamin dan selalu melakukan peningkatan produksi terhadap perikanan tangkap. Melalui bantuan yang tersedia dari program pemerintah, seharusnya dapat untuk ditingkatkan dan dirasakan secara merata oleh seluruh masyarakat nelayan di Kabupaten Pamekasan.

\section{DAFTAR RUJUKAN}

Ardianti, N. (2019). Program Pemberdayaan Ekonomi Masyarakat Pesisir. Jambi: Program Studi Ekonomi Syariah UIN Sulthan Thaha Saifuddin.

Arikunto, S. (2015). Dasar-Dasar Evaluasi. Jakarta: Bumi Aksara.

Bolkiah, A. S. (2016). Peran Dinas Perikanan dan Kelautan dalam Meningkatkan 
Kehidupan Ekonomi Masyarakat Nelayan di Desa Padelegan Kecamatan Pandewu Kabupaten PAmekasan Provinsi Jawa Timur. Jatinangor: IPDN.

Creswell, J. W. (2012). Educational research: Planning, conducting, and evaluating quantitative.. Upper Saddle River, NJ: Prentice Hall.

Iswari, I. G., Indrayani, L., \& Suwena, K. R. (2019). Pemberdayaan Masyarakat Pesisir dalam Upaya Meningkatkan Ekonomi di Dusun Pangkungdedari, Desa Melaya, Kecamatan Melaya. Jurnal Pendidikan Ekonomi Volume 11 No. 2, 509-516.

Karubaba, O., Purwanti, F., \& Suprapto, D. (2014). Evaluasi Program Pemberdayaan Masyarakat Pesisir di Desa Sarawandori, Kosiwo Kabupaten Kepulauan Yapen, Provinsi Papua. Jurnal Management of Aquatic Resources, 119-124.

Qodriyatun, S. N. (2013). Peningkatan Kesejahteraan Masyarakat Pesisir di Kota Batam melalui Pemberdayaan Masyarakat. Aspirasi Vol. 4 No. 2, 91-100.
Salam, A. A. (2008). Evaluasi Kebijakan dalam Implementasi Hukum Laut Internasional (UNCLOS) 1982 di Indonesia. Jakarta: Sekretariat Jenderal Satuan Kerja Dewan Kelautan Indonesia, Departemen Kelautan dan Perikanan.

Sidabalok, \& Marina, J. (2005). Pemberdayaan Masyarakat Nelayan di Jakarta (Studi Evaluasi Program Pemberdayaan Bantuan Paket Bergulir Sarana Penangkapan Ikan di Muara Angke-Jakarta Utara). Depok: Fakultas Ilmu Sosial dan Ilmu Politik Universitas Indonesia.

Sugiyono. (2015). Metode Penelitian Kuantitatif, Kualitatif, dan R\&D. Alfabeta: Bandung.

Surono, O. (2015). Koperasi Nelayan: Pengelolaan Sumber Daya Perikanan Tangkap Berbasis Ekonomi Gotong-royong. Jakarta: RMBOOKS. 
Virioner - Vol. $13 \backslash$ No. $2 \backslash$ Agustus 2021 